\title{
PELAKSANAAN SKRINING PERTUMBUHAN DAN PERKEMBANGAN PADA ANAK USIA DINI DI PAUD VICTORIA WARAT
}

\author{
Fransiska Nova Nanur ${ }^{1}$, Jayanthi Petronela Janggu ${ }^{2}$ \\ ${ }^{1,2}$ Program Studi Kebidanan Unika Santu Paulus Ruteng \\ Jalan Ahmad Yani Nomor 10 Ruteng Flores 86508 \\ e-mail: fransiskanova57@yahoo.com
}

\begin{abstract}
ABSTRAK
Saat ini program deteksi tumbuh kembang pada anak masih berfokus pada anak yang dicurigai mengalami keterlambatan tumbuh kembang saja. Sementara penemuan dini gangguan tumbuh kembang pada anak masih belum banyak dilakukan. Mengisi gap ini, kegiatan ini bertujuan untuk mengetahui pertumbuhan dan perkembangan anak dan mendeteksi secara dini bila terjadi penyimpangan. Kegiatan ini dilaksanakan dalam dua hari dengan jumlah peserta 20 anak. Alat dan bahan yang digunakan dalam kegiatan ini adalah bola, kubus, kertas manila, pulpen, krayon, boneka, baju dan formulir quesioner pra skrining perkembangan menurut usia, timbangan berat badan dan pengukurtinggi badan. Hasil kegiatan menunjukkan bahwa sebagian besar pertumbuhan dan perkembangan anak dikategorikan normal dalam perbandingan dengan usia, berat badan dan tinggi badan anak. Sementara beberapa diantaranya terdeteksi mengalami masalah. Untuk anak yang mengalami gangguan pertumbuhan dan perkembangan, kegiataan skirining ini harus rutin dilakukan.
\end{abstract}

\section{Kata Kunci : Anak, Pertumbuhan, Perkembangan}

\section{ABSTRACT}

The current program to detect the children'sgrowth and development just focus on the children which are definitely affected by growth and development disorder. While the early detection on children'sgrowth and development disorder still largely ignored. To that end, this program aims to know the children's growth and development in order to since early detect the developmental disorder. This program was conducted in two days on 20 children in PAUD Victoria Warat. In doing that, this program were used some tools, those are ball, cube, manila paper, pen, crayon, doll, clothe and pra-screening questioner based on age, weight and height. The results show that most of children's growth and development are normal, in comparison with their age, weight and height. While some of them are abnormal. For the children which are affected by growth and development disorder, this screening program must be carried out routinely.

\section{Key Words : Children, Development, Growth}




\section{PENDAHULUAN}

Anak-anak harus diberi peluang untuk berkembang secara penuh. Perkembangan anak yang memuaskan, terutama di tahun-tahun pertama kehidupan akan mampu memaksimalkan kemungkinan anak-anak untuk mendapatkan pendidikan dan menjadi warga negara yang sepenuhnya aktif dan mampu mengatasi perubahan hidup serta lebih jauh akan dapat mengurangi kesenjangan sosial dan ekonomi dalam masyarakat (Figueiras dkk,2012).

Sejumlah penelitian telah membuktikan pentingnya pertumbuhan dan perkembangan yang sehat pada tahun-tahul awal kehidupan anak. Anakanak yang mengalami keterlambatan dalam tumbuh-kembang awal, akan terus menunjukkan kinerja di bawah teman sebaya. Hal ini dapat berdampak pada hasil pendidikan, kehidupan sosial dan kehidupan umum yang lebih buruk (Honigfeld \& Lorentson, 2015).

Penting untuk diketahui bahwa pertumbuhan dan perkembangan fisik, kognitif, linguistik dan sosial emosional dalam lima tahun awal kehidupan seorang anak, terjadi dengan sangat cepat. Tidak semua anak dalam kisaran usia ini dapat mencapai pertumbuhan dan perkembangan yang ideal. Banyak anak yang mengalami gangguan tumbuh-kembang yang berpotensi membawa dampak negatif bagi anak

Penapisan dini untuk mengidentifikasi masalah potensial pada anak-anak sangat penting untuk dilakukan dalam rangka pertumbuhan dan perkembangan anak yang lebih sehat Sebagaimana yang telah diamanatkan Peraturan Menteri Kesehatan RI tahun 2014 yang menyebutkan bahwa pemantauan pertumbuhan, perkembangan dan gangguan tumbuh kembang anak merupakan bagian dari kegiatan pelayanan kepada bayi, balita dan anak prasekolah. Pemantauan itu penting dilakukan dalam rangka meningkatan kualitas tumbuh kembang anak usia dini dan kesiapan anak memasuki jenjang pendidikan formal.

Dengan mengetahui masalah pertumbuhan dan perkembangan sejak dini pada anak dapat diberikan perawatan atau intervensi yang efektif, sehingga dapat mencegah masalah yang lebih serius (Opre Report, 2014). Karena itu, skrining pertumbuhan dan perkembangan yang efektif harus dimulai sejak awal kehidupan seorang anak dan diulangi sepanjang masa kanak-kanak dengan menggunakan alat skrining yang valid.

Kegiatan skrining tumbuh kembang ini dilakukan di PAUD Victoria Warat. Berdasarkan hasil pengkajian awal ditemukan bahwa guru PAUD tidak memiliki pengetahuan tentang skrining tumbuh kembang dan hingga kini belum pernah dilaksanakan kegiatan skrining tumbuh kembang anak. Kegiatan pengabdian ini perlu dilakukan untuk menjawab persoalan di atas.

\section{METODE}

Kegiatan ini dilakukan dengan metode wawancara, pemeriksaan fisik dan beberapa latihan serta permainan. Wawancara, latihan dan beberapa kegiatan bermain dilakukan untuk menilai perkembangan motorik kasar, motorik halus, bahasa dan personal sosial. Sedangkan pemeriksaan fisik yang dilakukan berupa pengukuran tinggi badan dan berat badan bertujuan untuk mengetahui pertumbuhan anak.

Alat dan bahan yang digunakan dalam kegiatan pengabdian ini diantaranya bola, kubus, kertas manila, pulpen, krayon, boneka, baju dan kuesioner pra skrining perkembangan menurut usia, timbangan berat badan dan pengukur tinggi badan.

Kegiatan ini dilakukan dalam beberapa tahap yaitu: observasi lapangan dan koordinasi dengan pihak sekolah, persiapan alat dan bahan, pelaksanaan 
kegiatan yang meliputi pengukuran tinggi badan, penimbangan berat badan, anamnesa dan pemeriksaan dengan menggunakan kuesioner pra skrining perkembangan dan analisis hasil skrining.

\section{HASIL dan PEMBAHASAN}

Kegiatan skrining ini berlangsung selama dua hari dengan jumlah peserta 20 anak dengan rentangan usia 2-6 tahun. Hasi skrining pertumbuhan diperoleh dari pengukuran berat badan dan tinggi badan yang disajikan dalam tabel berikut.

Tabel 1. Berat Badan Menurut Umur

\begin{tabular}{lll}
\hline No & Kategori Status Gizi & N \\
\hline 1. & Gizi Baik & 19 \\
2. & Gizi Kurang & 1 \\
\hline
\end{tabular}

Hasil pengukuran berat badan menunjukkan bahwa sebagian besar anak berstatus gizi baik yaitu 19 orang dan terdapat satu orang anak yang memiliki status gizi kurang. Dalam konteks ini, status gizi merupakan salah satu indikator untuk mengukur keberhasilan pemenuhan kebutuhan nutrisi pada anak. Berdasarkan wawancara kami dengan orang tua anak, keadaan gizi kurang tersebut disebabkan karena pola makan anak yang salah. Anak jarang makan pagi dan lebih sering mengkonsumsi snack yang tidak sehat. Hal yang sama juga ditemukan dalam penelitian di Mojokertoyang menunjukkan bahwa pola makan yang tidak baik disebabkan karena orang tua cenderung mengikuti kemauan anak, serta tidak membiasakan anak untuk makan dengan teratur (Sa'diya, 2015).

Hasilpengukuran tinggi badan disajikan dalam tabel berikut:

Tabel 2. Tinggi Badan Menurut Umur

\begin{tabular}{lll}
\hline No & Kategori Status Gizi & $\mathrm{n}$ \\
\hline 1. & Normal & 16 \\
2. & Pendek & 1 \\
3. & Sangat Pendek & 3 \\
\hline
\end{tabular}

Hasil pengukuran tinggi badan menunjukkan bahwa terdapat tiga orang anak yang termasuk dalam kategori sangat pendek dan satu orang anak dengan kategori pendek. Berdasarkan hasil wawancara dengan orang tua si anak, penyebab utama dari keadaan itu adalah faktor genetik, yaitu orang tua si anak yang juga memiliki perawakan tubuh yang pendek. Hasil penelitian di Semarang Timur juga menyampaikan bahwa faktor genetik juga menjadi salah satu faktor risiko dari kejadian stunting pada balita (Narsikhah \& Margawati, 2012).

Selain faktor keturunan, rendahnya pengetahuan orang tua tentang gizi seimbang juga menjadi salah satu penyebab anak pendek. Hal ini didukung oleh pernyataan orang tua yang menyampaikan bahwa selama ini anak mereka cenderung hanya mengkonsumsi zat-zat gizi tertentu seperti karbohidrat dan protein, sedangkan vitamin, mineral, lemak sangat jarang dikonsumsi.

Hasil skrining perkembangan disajikan dalam tabel berikut:

Tabel 3.Hasil Skrining Perkembangan

\begin{tabular}{lll}
\hline No & Kategori Perkembangan & $\mathrm{N}$ \\
\hline 1. & Sesuai & 14 \\
2. & Meragukan & 3 \\
3. & Penyimpangan & 3 \\
\hline
\end{tabular}

Berdasarkan tabel di atas, dapat disimpulkan bahwa sebagian besar anak memiliki perkembangan yang sesuai dengan usianya dan sebagian kecil mengalami penyimpangan dan meragukan. Anak dengan kategori mengalami penyimpangan lebih cenderung bermasalah dengan motorik halus seperti tidak dapat menggambar, membuka dan mengenakan baju serta memasang tali sepatu.

Kegiatan ini sangat bermanfaat baik bagi anak, orang tua, maupun sekolah karena melalui kegiatan kita dapat mengetahui tumbuh kembang dan penyimpangan atau masalah yang terjadi, sehingga sedini mungkin dapat diatasi. 


\section{KESIMPULAN dan SARAN}

Berdasarkan hasil skrining yang dilakukan, ditemukan beberapa anak di PAUD Victoria Warat yang mengalami masalah tumbuh kembang. Oleh karena itu, penulis menyarankan agar anak yang mengalami masalah tumbuh kembang diberikan stimulus dan guru PAUD Victoria Warat perlu diberikan pelatihan skrining tumbuh kembang agar mampu melakukan kegiatan skrining ini secara rutin.

\section{UCAPAN TERIMA KASIH}

Ucapan terima kasih penulis sampaikan kepada yayasan Santu Paulus yang telah membiayai seluruh kegiatan ini. Ucapan terima kasih juga penulis sampaikan kepada Bapak Sifi Namal selaku kepala PAUD Victoria Warat yang memberi ijin dan memfasilitasi pelaksanaan kegiatan pengabdian ini.

\section{DAFTAR PUSTAKA}

Figueiras,A.,Souza,I.,Rios, V.,\&

Benguigui,Y. (2012). Monitoring Child Development (0-6 Years) In The Imci Context.United States: Pan American Organization.

Honigfeld, L.\&Lorentson, M. (2015).

Developmental Surveillance and Screening in Early Careand Education:Family and ProviderPerspectives. United States:Impact

Menkes RI.(2014). Permenkes Nomor 66 Tahun 2014 tentang Pemantauan Pertumbuhan, Perkembangan dan Gangguan Tumbuh Kembang Anak. Jakarta. Kemenkes RI.

Narsikhah, R.\& Margawati,A.(2012). Faktor ResikoKejadian Stunting Pada Balita Usia 24-36 Bulan di Kecamatan Semarang Timur Journal of Nutrition College,Volume 1, Issue
1, Pages 176-184. Diperoleh pada tanggal 25 Februari 2020 dari http://ejournal3.undip.ac.id

Opre Report.(2014).Early Childhood Developmental Screening: $A$ Compendium of Measures for Children Ages Birth to Five. United States: Department of Health and Human Services.

Sa'diya, L.K.(2015).Hubungan Pola Makan Dengan Status Gizi Anak Pra Sekolah Di PAUD Tunas Mulia Claket Kecamatan Pacet Mojokerto.Midwiferia Jurnal Kebidanan,Volume 1, Issue 2, Pages 69-77. Diperoleh pada tanggal 25 Februari 2020 dari https://ojs.umsida.ac.id 